\title{
Cuestión social, prácticas culturales y modelo asistencial en la modernidad liberal. Córdoba, Argentina, 1900-1930
}

\author{
BEATRIZ I. MOREYRA \\ Centro de Estudios Históricos Prof. Carlos S. A. Segreti-Conicet \\ Universidad Nacional de Córdoba/Universidad Católica de Córdoba \\ beamoreyra@fibertel.com \\ Nicolás Domingo MoretTi \\ Centro de Estudios Históricos Prof. Carlos S. A. Segreti-ConICET \\ Universidad Nacional de Córdoba \\ minguito1@hotmail.com
}

\section{Resumen}

Esta contribución tiene por objetivo estudiar las prácticas y representaciones culturales articuladas por las elites asistenciales como estrategias tendentes a lograr un consenso activo acerca del modelo benéfico asistencial y como mecanismos de legitimación y reproducción de las relaciones de poder imperantes en Córdoba en la modernidad liberal. Este consenso es entendido como el ordenamiento de las distintas configuraciones mentales para la percepción de la protección social como una cultura asistencial que consideraba que la atención de la pobreza y de los marginales era competencia de la filantropía y la beneficencia con la ayuda subsidiaria del Estado.

Palabras clave: cuestión social; beneficencia; prácticas culturales; representaciones; consenso; resistencia.

\section{Social Issues, Cultural Practices and Welfare Model in Liberal Modernity. Córdoba, Argentina, 1900-1930}

\begin{abstract}
This contribution seeks to study the cultural practices and representations proposed by the welfare elites as strategies for achieving an active consensus on the welfare model and as mechanisms for the legitimation and reproduction of the prevailing power relations in Córdoba in liberal modernity. This consensus is understood as the arrangement of the various mental configurations for the perception of social protection as a welfare culture that regarded poverty alleviation and the care of the marginalized as a matter for philanthropy and charity with the subsidiary support of the state.
\end{abstract}

Key words: social issue; charity; cultural practices; representations; consensus; resistance.

Fecha de recepción: Fecha de aceptación: 8 de febrero de $2013 \quad 24$ de octubre de 2013 


\title{
Cuestión social, prácticas culturales y modelo asistencial en la modernidad liberal. Córdoba, Argentina, 1900-1930
}

\author{
Beatriz I. Moreyra y Nicolás Domingo Moretti
}

\section{INTRODUCCIÓN}

A partir de los años ochenta del siglo $\mathrm{XX}$, las ciencias sociales y humanas experimentaron un resquebrajamiento del amplio proyecto consensual de la historia social y de la causalidad social y al mismo tiempo un movimiento de recuperación del análisis cultural como perspectiva de estudio capaz de intervenir de un modo significativo en algunos de los campos de discusión centrales de estas disciplinas. Es decir, parafraseando a Theda Skocpol, se asistió a un retorno de la cultura a un primer plano (Evans, Rueschemeyer y Skocpol, 1985, pp. 3-43). Ello implicó la confirmación del potencial cognitivo del estudio de la cultura, transformado en instrumento central para captar el sentido de una época (Eley, 2009, p. 151). Es decir, comenzaron a cuestionarse los dualismos que predominaban en las ciencias sociales y humanas, rechazándose la necesidad de optar entre valores y relaciones sociales, pues ambos son interdependientes y se refuerzan mutuamente. Este deslizamiento consideró a lo cultural como la expresión simbólica de la conducta social que gozaba de la misma "realidad" que los considerados hechos sociales objetivos. Es decir, el giro cultural con el énfasis en la cultura y el lenguaje socavó el enfoque jerárquico en la explicación de las realidades sociales y postuló como supuesto esencial que toda realidad social está culturalmente construida y constituida discursivamente.

La incorporación de la dimensión sociocultural tuvo un impacto notable en la explicación histórica, porque se comenzó a reconocer la importancia de los factores subjetivos en la comprensión de los hechos y procesos sociales. El énfasis en la cultura supone que las creencias y los rituales interactuaban con las expectativas sociales y económicas de la población y no sólo reflejaban su situación socioeconómica.

En esta perspectiva, Hans Medick ha afirmado que la cultura no se refiere únicamente a un tema específico, ella no es considerada solamente como un subsistema social que es relativamente estático y limitado a sí mismo, sino que la cultura alude a un factor dinámico y formativo en la "realización” de cada día y en la transformación de las relaciones sociales, económicas y políticas. La cultura y las expresiones culturales no pueden ser decodificadas simplemente como un sistema de normas, símbolos y valores que están presentes y "dados", constantes e invariables en todas las relaciones cotidianas y no cotidianas. Por el contrario, precisamente desde la perspectiva proveniente de la antropología 
social y cultural, la cultura y las expresiones culturales deben ser exploradas como un elemento y un medio de la activa construcción y representación de las experiencias y relaciones sociales y sus transformaciones. Los modos culturales y las formas de expresión están así presentes como un motor histórico, como un elemento que modela las expectativas, los modos de acción y sus consecuencias en el hecho histórico y también operan como factores en la estructuración del mundo social de la clase, la autoridad, las relaciones económicas y su transformación histórica. ${ }^{1}$

Estos virajes afectaron también los estudios e interpretaciones sobre la cuestión social y los modelos de asistencia social, proporcionando una visión más compleja y matizada de las políticas sociales. Dentro de este cambiante contexto historiográfico, el interrogante central que atraviesa este trabajo es por qué después de tres décadas de diversas iniciativas reguladoras por parte del estado provincial y municipal sobre la cuestión social, de los deslizamientos discursivos a favor de una mayor equidad en la distribución del bienestar y de la necesidad del reconocimiento de los derechos sociales, siguió prevaleciendo un modelo asistencial con fuerte participación de las instituciones civiles de protección social.

${ }^{1}$ La mayoría de los historiadores que adoptaron el giro cultural nunca abandonaron la creencia en la realidad objetiva del mundo social y sostuvieron que lo cultural y lo social eran indisociables. Por el contrario, la creciente atención al lenguaje y a las estructuras discursivas condujo al desplazamiento del foco de la investigación histórica desde el fenómeno social al discurso y a través de la ortodoxia textual se sostenía que el discurso producía el sujeto, que no constituía un agente dotado de libertad y conciencia, sino más bien una posición creada por el discurso.
Muchas respuestas se han explorado. En algunos casos se han enfatizado, entre otros factores, las limitaciones de las capacidades estatales -administrativas y financieras- para atender las demandas sociales en la coyuntura histórica analizada; ${ }^{2}$ otros estudios han resaltado la centralidad del liberalismo y su escasa preocupación por lo social y/o la conveniencia económica de derivar la atención social de los sectores más empobrecidos al ámbito de la sociedad civil en calidad de deber moral (véanse Castel, 1997; Moreyra, 2009a). ${ }^{3}$ Menos atención se ha prestado a las prácticas culturales como mecanismos de legitimación de un modelo de asistencia social, más allá de la racionalidad disciplinadora que ha estado siempre presente en las interpretaciones esgrimidas.

En este marco, este artículo se propone ofrecer una interpretación integradora que, sin descuidar los factores políticos, económicos e ideológicos, rescate el poder es-

\footnotetext{
${ }^{2}$ Entre otros trabajos, para el caso de Córdoba véase Moreyra (2000), y Remedi (2001).

${ }^{3}$ En este sentido, en los mensajes de los intendentes elevando los presupuestos y en los debates sobre ampliación de partidas, estaba muy presente la preocupación prioritaria por el equilibrio fiscal y la deuda pública y por no expandir los gastos más allá de lo que consideraban servicios indispensables. La reiteración de esta idea de "economizar" se convirtió en uno de los fundamentos más sólidos que sustentaba la vigencia del modelo benéfico asistencial. En 1924, respecto a delegar a las damas de la sociedad de beneficencia el mantenimiento de las casas de inquilinato municipal, este argumento aparecía con meridiana claridad: "en resumidas cuentas, no se trata de dádiva, sino de una operación conveniente para la comuna pues las casas son municipales y las damas las refaccionan con la mitad de gastos que tendrá que hacer la municipalidad para ese fin, así es conveniente darle todo lo que ellas piden para esa reparación”.
} 
tructurante de las prácticas culturales. Esta visión de la cultura como un factor estructurante implica considerarla no solamente como un sistema coherente de símbolos y/o como mecanismo de control que gobierna la conducta, sino que la concibe como posibilidad de agencia de los individuos, dada la ambigüedad del mundo simbólico, la pluralidad de interpretaciones posibles y las luchas entabladas por los recursos tanto simbólicos como materiales. El objetivo es desentrañar cómo se configuran, se negocian y se transforman las significaciones a través de las prácticas, las representaciones, los imaginarios y la eventualización como espacios y procesos de producción de sentido a través de los diferentes y contrapuestos ámbitos sociales (Hering y Pérez, 2012, p. 27).

Esta concepción de lo cultural ha sido, precisamente, el fundamento del cuestionamiento a las perspectivas basadas únicamente en la suficiencia explicativa de los mecanismos disciplinadores y la ponderación de otras variables explicativas, como son la generación de un consenso activo por parte de los asistidos con los modelos de atención social y con los fundamentos ideológicos y políticos subyacentes a la cultura benéfico-asistencial de las elites dirigentes. Ellas no sólo utilizaron mecanismos de control social sino también se valieron de prácticas culturales para cimentar y reforzar ese consenso entre los asistidos, buscaron inculcar un sentido social de pertenencia entre los protegidos que les permitiera identificarse como tal y actuar en consonancia. En otras palabras, se perseguía que, a través de una identidad de proyecto, los participantes, tomando como referentes los materiales culturales que se les presentaban a su percepción y apropiación, construyeran una identidad que redefiniera su posición en la institución y en la sociedad. Es decir, que el individuo en sus prácticas sociales reconociera a los demás como miembros de la misma comunidad y se viera como parte de ella al ser reconocido por los otros en su situación de dependencia. En síntesis, nos proponemos rescatar las prácticas y representaciones en la construcción compleja de ese consenso activo, entendido como el ordenamiento de las distintas configuraciones mentales para la percepción del mundo social por los actores sobre la base de la fuerza estructurante de una cultura asistencial fuertemente arraigada en la sociedad, las instituciones y los hombres -asistentes y asistidos-, que consideraba que la atención de la pobreza y de los marginales seguía siendo competencia de la filantropía, la beneficencia y de la "caridad oficial reglamentada y fría”, pero caridad necesaria.

Este propósito direccionado por las elites asistenciales adquiere mayor importancia si se consideran dos aspectos interrelacionados. En primer lugar, como Michel de Certau ha argumentado, las formas culturales, los actos o los artefactos nunca han tenido un significado fijo, por cuanto el sentido se atribuye durante la apropiación individual o colectiva (Hering y Pérez 2012, p. 27).

Si las categorías culturales, como fenómenos históricamente constituidos, están sujetas constantemente a los efectos de la reevaluación funcional y resignificación por parte de los agentes, nunca pueden ser totalmente estabilizadas (Moreyra, 2007, pp. 153-182). En segundo lugar, y en íntima relación con lo anterior, la dudosa efectividad de las interpretaciones ortodoxas sobre las políticas de control social puesta de manifiesto en la heteroge- 
neidad de las formas en que las personas las apropiaron, reelaboraron o resistieron en sus vidas. ${ }^{4}$ Esta mirada, considerada desde el punto de vista de su propia y especial dimensión interpretativa, potenció la importancia explicativa de las estrategias de las elites asistenciales encaminadas a configurar, modificar y reconvertir, según las cambiantes circunstancias históricas, los mecanismos de interacción social, reciprocidad y control, tendentes a la legitimación del modelo asistencial.

Por otra parte, la cultura no es apolítica. Las expresiones y prácticas culturales son también mecanismos de reproducción de las relaciones de poder imperantes; es decir, la cultura como una red de significaciones, en las que se dirimen o refuerzan las relaciones de poder. La cultura, como la sociedad, es un campo de juego con sus límites y sus armonías internas menos aparentes, en el cual actores y grupos compiten por posiciones de poder; concretamente, por el control de los significados.

Para demostrar el poder configurativo y cambiante de las prácticas culturales, la investigación pone énfasis en dilucidar el heterogéneo universo de las mismas, su función pedagógica y sus estrategias de control y de poder. En otras palabras, el sistema de protección social era también una construcción cultural dotada de significación política, recursos simbólicos y rituales sociales (Moreyra, 2009a, pp. 13-26).

En este sentido, el artículo analiza las fiestas, rituales y conmemoraciones con sus productos y artefactos culturales -cantos, himnos alusivos, poesías, discursos y otras formas literarias-, la actividad edi-

\footnotetext{
${ }^{4}$ Entre otros trabajos que cuestionan la ortodoxia de estas interpretaciones véase Di Liscia y Boholavsky (2005, pp. 9-25).
}

torial, los momentos de esparcimiento -como las representaciones teatrales y el cine- y los espacios de lectura, que constituyeron herramientas culturales de profundas implicancias políticas, ideológicas e identitarias, a través de las cuales las elites asistenciales se proponían generar un sentimiento compartido e identidad común, una comunidad emocional y fueron esenciales para transmitir ideas y dar respuestas a las preocupaciones sociales; es decir, se procuraba generar espacios donde los asistidos se reconocieran, generaran vínculos con sus protectores, reconocieran las jerarquías sociales y adoptaran un modelo de sociedad y lo difundieran entre ellos. Pero el trabajo no sólo se focaliza en la conformación de un consenso con la acción social desplegada por las instituciones, sino que también aborda las tensiones y resistencias que traía aparejado el proceso de apropiación de las prácticas culturales. La apelación al modelo benéfico asistencial devino así una respuesta funcional a las manifestaciones más críticas de la cuestión social en un contexto en que la acción estatal no era sólo subsidiaria, sino que el Estado mismo consideraba que la acción de las entidades civiles era más adecuada desde el punto de vista económico y de la cultura asistencial predominante consustanciada, especialmente en las dos primeras décadas del siglo $\mathrm{XX}$, con la protección y ayudada brindada por las asociaciones y damas católicas.

LA CUESTIÓN SOCIAL, EL DESARROLLO DEL MODELO BENÉFICO ASISTENCIAL Y LOS ENFOQUES HISTORIOGRÁFICOS

Hacia finales del siglo XIX y principios del xx, Argentina mostraba los alcances 
de un proceso de expansión económica que había iniciado años antes y que, sustentado sobre las bases del desarrollo de la exportación de bienes primarios, materializaba el ideal de progreso y modernización del país anhelado por la elite gobernante. Sin embargo, este proceso de transición hacia la modernización, exteriorizado en el anhelo de lograr la transformación económica, el progreso material y una sociedad ordenada, integrada, saludable y culta, no estuvo acompañado por una redistribución significativa del poder y de la riqueza, sino que, por el contrario, involucró la marginación y la exclusión de vastos sectores sociales que experimentaron en sus vidas necesidades básicas insatisfechas y la ausencia de oportunidades que impedían el desarrollo integral y participativo de los ciudadanos (Moreyra, 2009a, p. 15). En este sentido, la emergencia de la denominada cuestión social consecuencia del proceso de modernización en Argentina, comprendía un conjunto de problemas como el pauperismo y la marginalidad, la aparición de carencias médico-sanitarias y de salubridad, la propagación de enfermedades y epidemias, el hacinamiento habitacional, la difusión de "males sociales" (criminalidad, prostitución), los conflictos del mundo del trabajo, el surgimiento de instituciones orientadas a defender los intereses de los trabajadores desde el punto de vista gremial, ideológico y político y la difusión de ideologías radicalizadas, que representaban una amenaza de fractura de la sociedad.

Ante estos problemas, las elites dirigentes se enfrentaron al temor de una posible pérdida de control sobre los sectores populares, por lo que fue tomando forma un conjunto de acciones para atenuar el déficit que caracterizaba el estado material y moral de los más empobrecidos y para resolver un problema que se tornaba una amenaza evidente para el orden público (Suriano, 2000, p. 3). Así, la modernidad liberal incluyó un proyecto civilizador que pretendió moralizar las costumbres, encauzar los comportamientos y promover gestos y valores que hicieran posible alcanzar la condición de "honorabilidad cívica", implantando un modelo de pedagogía social tendente al progreso moral, la paz social y el orden político (Lionetti, 2005, pp. 1225-1259).

En ese marco, las principales respuestas a la cuestión social provinieron, inicialmente, de un conjunto asistencial que respondía a un modelo pluralista no planificado con fuerte predominio de la beneficencia privada y una limitada participación del Estado. La tupida y dispersa red asistencial que desarrolló diversas texturas, comprendía un buen número de congregaciones religiosas, sobre todo femeninas (las mercedarias, las concepcionistas, las dominicas, las adoratrices, las franciscanas, etc.) y asociaciones seglares dedicadas al ejercicio de la caridad como las sociedades de beneficencia de la capital y de las ciudades del interior, las Damas de la Misericordia, las Damas de la Providencia, la Asociación de la Inmaculada Concepción, la Corte de las Mercedes y las Conferencias de San Vicente de Paul -entre otras- que regenteaban una variada tipología de asilos y hospitales. A ellas se sumaban diversas instituciones ideadas para el reparto de limosnas, especialmente alimentos y vestidos (comedor de pobres de la Liga Argentina de Damas Católicas y ollas populares en algunos barrios), una gama de iniciativas mixtas que combinaban la instrucción popular y profesional con la beneficencia, la moralización y la 
catequización (la escuela para aprendices y obreros adultos, escuelas dominicales, escuelas para servicios domésticos de la asociación Propaganda Católica, talleres de las Hijas de María, asilo y taller de la Sagrada Familia, Taller del Niño de Dios, etc.), escuelas de artes y oficios para niños pobres y los círculos obreros (véanse Eraso, 2009; Vagliente, 2010; Vidal, 2002; Vidal, 2012, entre otros). Las principales ciudades y pueblos del interior provincial reproducían, en menor escala, ese modelo de asistencia social de la ciudad capital consistente en una dispersa red asistencial de asociaciones de fuerte filiación religiosa que atendía las necesidades apremiantes de los sectores carenciados.

En un periodo de fuerte liberalismo económico, la cuestión social debía resolverse mediante una política sin Estado que no comprometiera a la estructura estatal o lo hiciera sólo en parte mediante políticas de reglamentación y control. Además, el desarrollo de ese modelo se anclaba en la creencia de que el pobre sólo tenía derecho a la protección y que la misma se cumplía por medio de la filantropía y la beneficencia (Moreyra, 2009a, p. 17).

Con respecto a las perspectivas de análisis, en las últimas décadas del siglo Xx la historiografía sobre la cuestión social y las políticas sociales manifestó una preocupación por dilucidar el papel de los actores no estatales en los modelos de asistencia social prevalecientes en la modernidad liberal en Latinoamérica. Esta atención obedeció al creciente interés de los historiadores sociales por los procesos institucionalizadores del mundo social, especialmente por el papel del Estado y de las instituciones de la sociedad civil, lo que se hizo extensivo a la actividad política, que dejó de percibirse como una cuestión extraña al campo de estudio (Moreyra, 2009b, p. 363). Por su parte, la crisis del Estado de bienestar produjo, además, un revival académico de los estudios dedicados al papel de las instituciones de la sociedad civil en la historia de los modelos de asistencia social. Pero lo más significativo fue que esta resignificación implicó también un deslizamiento en los marcos interpretativos de los modelos de asistencia social consistente en un cuestionamiento a la visión canónica caracterizada por el desarrollo de un enfoque excesivamente teleológico de la historia del bienestar, que consideraba los servicios sociales públicos y estatales como superiores en relación con la esfera ineficiente y particularista de la caridad voluntaria. Por otra parte, esa perspectiva se caracterizó por un excesivo apego a explicaciones exclusivamente unidimensionales en torno a la suficiencia explicativa de los mecanismos de control social, que inspiraron una pléyade de estudios que ponían el acento en los mecanismos de coacción moral tendentes al control de las clases subalternas y de las poblaciones reputadas como peligrosas, para aumentar los beneficios de la clase dirigente y para la estabilidad del orden social (Moreyra, 2009b, p. 364).

Pero a partir de los años ochenta del siglo $\mathrm{XX}$, una nueva perspectiva -en un contexto permeado por las críticas al Estado benefactor y la voluntad del Estado de transferir responsabilidades al mercado, a las asociaciones voluntarias y a los individuos- planteó una revalorización del papel de las asociaciones civiles en los análisis históricos de los modelos asistenciales y, por ende, una ponderación del modelo mixto de asistencia social entre el 
Estado y la sociedad civil. Por otra parte, el colapso de los regímenes comunistas estimuló también el interés por la sociedad civil y el énfasis en la importancia de la democracia. Esta visión renovadora hizo suya los aportes del giro cultural en los estudios sociales e históricos al considerar a la caridad y la beneficencia como mecanismos culturales extraordinariamente flexibles. Con esta mirada culturalista, se han indagado el lenguaje, el simbolismo y los rituales de la caridad y cómo ella es producida discursivamente.

\section{FIESTAS Y CONMEMORACIONES}

La fiesta era inherente a toda organización sociocultural y constituía una celebración que no sólo evocaba un objeto o acontecimiento, sino que mostraba y patentizaba el valor que se le otorgaba. Se vinculaba con el ámbito de lo colectivo, con la sacralización, la resacralización y con los procesos de identidad. En lo formal, estaban constituidas por rituales, conjunto de acciones sucesivas cargadas de sentido, con un determinado fin y efectuados en espacios cuya entidad poseía un simbolismo particular. Los ritos reforzaban los tradicionales vínculos sociales entre los individuos; hacían resaltar el modo en que la estructura social de un grupo se veía fortalecida y perpetuada por la simbolización ritual o mítica de los valores sociales subyacentes en que ella descansaba.

La construcción de espacios de identidad en las asociaciones se efectuó sobre esa base simbólica donde tenían suma importancia las celebraciones en conmemoración de los acontecimientos más significativos. En efecto, la rutina cotidiana, inmersa en carencias importantes, era periódicamente alterada por las fiestas organizadas en el interior de los establecimientos que permitían la interacción entre el asistente y el asistido, la visibilidad de la obra caritativa, el control del tiempo libre y la ritualización de la legitimidad del modelo de interdependencia del Estado y las asociaciones. Así, las fiestas y demás expresiones de sociabilidad institucional eran utilizadas como un fenómeno de cohesión de la comunidad y el ritual festivo como elemento activador de las identidades. Las imágenes, los símbolos, los emblemas, los estandartes presentes en las celebraciones eran formas simbólicas a las que se apelaba para lograr que el individuo generara cohesión social y actuara de acuerdo con las exigencias del grupo que los acogía y le brindaba los medios para subsistir y para integrarse al medio "civilizado".

A través de su exteriorización, las fiestas institucionales eran una instancia valedera para exhibir los logros de la acción social benéfica en diferentes espacios dedicados a difundir los contenidos del proyecto civilizador, de la educación y del control de los sectores empobrecidos y excluidos. Las elites gobernantes reivindicaban el manejo de los pobres y el ordenamiento de la pobreza que las asociaciones emprendían aunque ello significara una posición de poder.

En este sentido, es ilustrativo el caso de la denominada "fiesta angélica" dedicada a los niños, que se realizaba anualmente en Río Cuarto por la Conferencia Vicentina de Santa Rosa de Viterbo. Para esas ocasiones, se les obsequiaba a los niños con objetos piadosos, masas, caramelos y rifas a la par que se les inculcaba mediante cánticos alusivos la grandiosidad del acto celebratorio. Después de la misa, más de 
2500 niños recorrían las calles de la ciudad, llevando las imágenes protectoras en andas y numerosos estandartes de los centros catequísticos, coreando cánticos piadosos que constituían un factor esencial en la construcción de representaciones. En este aspecto, también se destacó la obra de los distintos círculos de obreros, en cuyas sedes se instalaron bibliotecas populares y se realizaron fiestas. ${ }^{5}$ En efecto, cada círculo tenía un local para recreo de los socios los días domingos y feriados, organizándose bandas de música, cuadros dramáticos y pequeñas orquestas.

Otro canal eran las celebraciones de las bodas de plata de las asociaciones u otras fiestas conmemorativas consideradas como la unión de los ideales y la festiva alegría de los éxitos, ocasiones en donde, además de la retórica discursiva de los oradores, se realizaban representaciones teatrales, poesías e himnos alusivos de carácter laudatorio y conmemorativo. En este sentido, en 1918 adquirió ribetes destacados la fiesta cómica lírica musical en el asilo de Santa Infancia, donde se representaban los cuadros vivos "La caída de Luzbel" y "Dios y patria", que inculcaban los sentimientos del deber y de amor a Dios. ${ }^{6}$ En cada una de estas celebraciones -como fueron las de los Círculos de Obreros- el programa constaba de dos partes: una que comprendía los actos eclesiásticos y piadosos, y otra, la velada literario musical donde se representaban piezas como Piedad, cuadros plásticos de tres momentos alusivos a la patria, la libertad y la paz y otros sobre la Misión de los Círculos Obreros, el tango Haragán y

${ }^{5}$ Memoria del ejercicio 1919-1920 de las Conferencias de las Señoras Vicentinas de Santa Rosa de Viterbo Río Cuarto, 1922, pp. 19 y 20.

${ }^{6}$ Los Principios, 29 de octubre de 1918, p. 5. el Himno o Marcha Final. Esta sociabilidad conmemorativa donde se hacía gala de una discursividad celebratoria de las prácticas caritativas se convertía así en una ocasión para exaltar las virtudes de la acción social cristiana.

Ribetes similares alcanzaron los festejos de las bodas de plata de la Pía Unión de San Antonio de Padua que culminaron con un himno de la institución que ensalzaba los beneficios de la pertenencia institucional. Los actos conmemorativos del VII Centenario de la Orden Tercera Franciscana, que adquirieron gran relevancia, consistieron en la celebración de la Semana social franciscana, con veladas literarias, musicales, conferencia del secretario de la Unión Popular Católica Argentina y una rifa gratuita de terrenos cedidos por los miembros de la Orden para la edificación de viviendas obreras.

Otra eventualización de contornos relevantes fueron las conmemoraciones salesianas, ejemplo paradigmático del ritualismo asociativo. Los salesianos, llegados a Córdoba en la primera década del siglo pasado, emprendieron su labor educativa con fuertes contenidos de pedagogía social, fundada en la formación técnico profesional de los niños y jóvenes marginados y de escasos recursos. Ellos alternaron la vida interna de sus obras e institutos con una importante presencia pública en las calles de la ciudad. Aniversarios, actos conmemorativos, inauguraciones, premiaciones, bendiciones y hasta las fiestas propias del calendario litúrgico y del santoral salesiano eran moti-

${ }^{7}$ Memoria presentada ante la V Orden Tercera Franciscana de Córdoba, correspondiente al periodo terminado el 11 de junio de 1922, Córdoba, 1922, pp. 3-29. 
vos suficientes para desplegar todo un aparato ceremonial en donde la solemnidad de los actos manifestaba la importancia dada por los organizadores a esta clase de eventos.

La participación en varias oportunidades de las máximas autoridades de gobierno de la provincia y la ciudad se cumplía gracias a las gestiones de los cooperadores ${ }^{8}$ vinculados estrechamente con la clase dirigente. En este sentido, desde un primer momento, nombres fuertes del ámbito político local, desde concejales, legisladores, ex ministros, hasta gobernadores e intendentes, formaron parte de la misma comisión de Cooperadores Salesianos. Los estrechos vínculos creados con la elite dirigente civil y eclesiástica aseguraron a los salesianos, no sólo la indispensable ayuda material de aquellos "caballeros distinguidos, honorables y progresistas”, sino la legitimación necesaria para poder actuar y hacer prosperar su obra. Para la ocasión del primer gran acto realizado por los salesianos en Córdoba, a fines de 1905, el gobernador de la provincia José Vicente Olmos y el intendente municipal doctor Alejandro Ortiz, junto con el prelado diocesano Monseñor Zenón Bustos y los representantes del clero regular y de todas

\footnotetext{
${ }^{8}$ Los Cooperadores Salesianos era una institución creada por el fundador de los salesianos, Don Bosco, para formalizar el aporte económico y todo tipo de ayuda que las personas de buena posición realizaban para el sostenimiento de su obra, constituyendo, además, una suerte de apostolado entre las clases altas. Así, miembros de la elite social, "personas distinguidas", "caballeros respetables", "familias acomodadas", ayudaron con donaciones y colectas, hicieron uso de sus influencias y realizaron una ininterrumpida propaganda en los periódicos de la época a favor de la acción educativa de los sacerdotes italianos.
}

las órdenes religiosas 9 ocuparon un lugar en el "ancho tarimado" construido en las precarias instalaciones del Colegio Pío X. La misma confluencia de autoridades civiles y eclesiásticas fue la tónica de los actos realizados con motivo de la inauguración del nuevo edificio destinado a la Escuela de Artes y Oficios en mayo de 1907, con la presencia del gobernador electo doctor Ortiz y Herrera, el vicegobernador doctor Félix T. Garzón y un gran número de "distinguidos caballeros y damas de la "baute social". ${ }^{10}$ La frecuente asistencia de las significativas figuras del ámbito político y eclesiástico envestía de jerarquía un evento que pretendía, entre otras cosas, captar la adhesión de la comunidad en general, particularmente de aquellos que estaban en mejores condiciones para colaborar con su sostenimiento, de la misma manera que también legitimaba el accionar educativo de la congregación. Por otro lado, la participación asidua en los actos de altos funcionarios gubernamentales junto con los numerosos cooperadores salesianos, da cuenta de la estrecha interacción existente entre el Estado y la elite asistencial en la atención de las demandas sociales en ese periodo.

El programa de los actos también destinaba un importante espacio a los discursos, donde los oradores manifestaban su adhesión a la obra y legitimaban el apoyo brindado a la labor educativa y civilizadora de los salesianos, apuntando a los enormes beneficios que este tipo de iniciativas reportaban para la comunidad. En varias ocasiones, la prensa local solía incluir los discursos más sobresalientes

${ }^{9}$ La Patria, 4 de diciembre de 1905, p. 3.

${ }^{10}$ La Patria, 10 de mayo de 1907, p. 1. 
luego de la crónica del acto, dando mayor difusión a las ideas que, generalmente, también aparecían impresas en pequeños opúsculos o folletines a manera de recuerdo para los asistentes.

En estos actos, la recepción dispuesta para las autoridades adquiría, según la magnitud del evento, grandes proporciones. Con motivo de la conmemoración del cincuenta aniversario de la llegada de los salesianos a Argentina, tuvo lugar, en 1924, quizás la mayor puesta en escena de las dos primeras décadas. En un marco festivo que se extendió a lo largo de siete días, titulado la "Semana salesiana", se desarrolló un imponente desfile de alrededor de mil alumnos de los colegios salesianos por las calles de la ciudad. Partiendo de la puerta del colegio Pío X, la columna abarcó un extenso recorrido de varias cuadras, pasando al frente del arzobispado, la casa del gobernador y del intendente. En cada una de las estratégicas paradas realizadas, varios alumnos pronunciaron sendos discursos ante el obispo, el gobernador y el intendente, donde expresaban palabras de agradecimiento hacia las autoridades por la ayuda dispensada a la obra de Don Bosco en Córdoba, dejando además en evidencia los valores y principios en los cuales eran educados. En su discurso, uno de esos alumnos, al detenerse la columna frente a la casa del gobernador, declamaba:

Traemos el saludo de los mil niños salesianos que en estos momentos veis desfilar ante la bandera de la patria, enarbolada en esta casa, asiento de gobierno. Recibid, excelentísimo señor gobernador y distinguidos señores, el homenaje que en estos instantes la obra de Don Bosco tributa al gobierno, a la sociedad y al pueblo de Córdoba, por el cariño con que siempre le han favorecido. Amor a
Dios, amor a la Patria, amor a la virtud y al trabajo; he ahí señores, nuestros ideales; eso es lo que se nos enseña y eso es lo que queremos practicar para llegar a ser dignos argentinos. ${ }^{11}$

Además de escenificar la alianza entre las elites y los detentadores de las instituciones respecto al tratamiento de la cuestión social, estos actos y celebraciones constituían una manera de abrir las puertas de la institución al espacio público, para mostrar los alcances del proyecto sociopedagógico y las trazas de la modernidad en el interior de la institución, en el oratorio y en el colegio. En esos eventos singulares pero funcionales a la operatividad social del modelo educativo salesiano, los alumnos tenían una activa participación en el programa de los festejos. En este sentido, los salesianos daban una gran importancia a la enseñanza de la música entre los internos. Los superiores aspiraban a "que la música se cultivase en todas sus casas como un poderoso elemento de educación y un fuerte aliciente para llevar el pueblo a la piedad" (Vespignani, 1922, p. 238). En consonancia con esa aspiración, una de las primeras tareas realizadas por los salesianos apenas llegados a la ciudad fue la creación de un coro y una banda de música formados por los niños y jóvenes. Si en un primer momento se dedicaron a amenizar las funciones religiosas mediante cánticos piadosos y melodías alegres para los días de fiesta, pronto comenzaron a tomar parte de diferentes celebraciones, actos y festividades realizadas más allá de los muros del colegio. Las actuaciones públicas de los

${ }^{11}$ Los Principios, 23 de octubre de 1924, p. 7. 
pequeños músicos fueron en aumento llegando a tomar parte de importantes manifestaciones públicas, como el caso del Congreso de la Federación Católica de Córdoba realizado en el mes de octubre de 1918, en donde encabezaron una manifestación de 60000 personas, ejecutando las estrofas del himno nacional. ${ }^{12} \mathrm{El}$ paseo de estos alumnos por las calles de la ciudad, con su uniforme característico y el sonido de los instrumentos ejecutados, constituyó un espectáculo recreativo y un espacio de sociabilidad para los vecinos del barrio y los demás habitantes de la ciudad y representó un mecanismo muy potente para exhibir y difundir la labor civilizadora llevada a cabo con aquellos niños callejeros que se tenían por futuros elementos de desorden. A su vez, la participación de estos niños y jóvenes en actos y celebraciones públicas tan relevantes en la vida de la ciudad, favorecía la interacción y la adhesión con un grupo y un proyecto determinados. De esta manera, a través de estas fiestas y conmemoraciones, las elites asistentes se apropiaron del espacio público, con la consecuente profundización del consenso social.

Como el trabajo era considerado el principal elemento de regeneración y la herramienta más eficaz para borrar los vicios del ocio y la vagancia, los salesianos aprovechaban las festividades y conmemoraciones para mostrar los logros alcanzados por los alumnos artesanos de la Escuela de Artes y Oficios mediante la realización de exposiciones con los trabajos realizados. Así, sacos, pantalones, chalecos, sotanas, sobretodos, mesas, cuadros, botines, todo confeccionado en los talleres

\footnotetext{
${ }^{12}$ Los Principios, 15 de octubre de 1918, p. 5.
}

de sastrería, zapatería y carpintería, eran expuestos por varios días y, en algunos casos, la muestra era instalada fuera del colegio mismo, como en los salones del Club Católico, favoreciendo la visita de un público más numeroso que pudiera apreciar la importante labor social y educativa que se realizaba.

Finalmente, los rituales sociales organizados a través de colectas, funciones y festivales de caridad -como los realizados el "día de la flor", "de la casa cuna", "del tuberculoso", "los premios a la virtud"por una tupida y dispersa red asistencial de congregaciones religiosas -sobre todo femeninas-, constituían no sólo una objetivación de ese modelo mixto de acción social, sino una estrategia tendente a generar un sentimiento de pertenencia a una comunidad determinada, una recreación simbólica de las fuentes de legitimidad de ese modelo de protección social, un mecanismo para reforzar el consenso de los diversos sectores sociales y, fundamentalmente, un espacio privilegiado para generar una relación de reciprocidad entre asistente y asistido. La siguiente descripción de uno de esos eventos deja percibir estas múltiples representaciones:

el Taller de la Asunción de la Corte Sabatina de la Compañía de Jesús que preside doña Laura Carranza de Del Viso y a quien secundan las señoras Rosa Tiseira de Del Viso y Felisa Luque, interpretando la buena voluntad del gobierno de la provincia consiguió la donación de una suma de dinero con el propósito de distribuir ropas a los pobres. Esta efectuóse el 15 del corriente mes en la plazoleta frente al templo de la Compañía y en el edificio de los Josefinos, obsequiándose con trajes y alimentos, sirviéndose a la vez un desayuno a cien mujeres del pueblo. El acto 
resultó muy simpático, habiendo concurrido a él las autoridades provinciales, varios sacerdotes y numerosas damas. La banda de la escuela Presidente Roca ejecutó varias piezas de su repertorio. ${ }^{13}$

Los espacios de reclusión como las cárceles también fueron objeto de atención mediante la organización periódica de fiestas consistentes en la representación de una zarzuela cómica con lo cual se buscaba romper "la enervante monotonía que se encierra dentro de aquellas cuatro murallas". ${ }^{14}$ En el asilo de varones, además de atender las necesidades materiales, se procuraba la reforma moral por medio de un trabajo consciente y sostenido en conversaciones familiares, conferencias y misiones. ${ }^{15}$

En sus actos, las diversas instituciones otorgaban centralidad a los momentos piadosos, como las ceremonias de bendición y las misas. En ocasión de inaugurarse la primera parte del edificio de los salesianos, el programa contempló la bendición de varios salones y de nuevas máquinas para los talleres de la Escuela de Artes y Oficios, de los instrumentos nuevos para la banda de música del colegio y de los uniformes del batallón de exploradores. La bendición, además de acompañar y ser parte de la inauguración, era una forma de agradecer y hacer extensiva la "gracia del Señor" hacia aquellos que habían colaborado en la adquisición de aquellos

13 Actas del Concejo Deliberante. Año 1916. T. A-1-43, f. 228. Archivo Histórico Municipalidad de Córdoba (AHMC), Argentina.

${ }^{14}$ Memoria de la Juventud Antoniana de Río Cuarto, Año 1919.

${ }^{15}$ Serie Documentos. Año 1905. T A-2-34, f. 225. AHMC, Argentina. elementos materiales, lo que constituía otra forma de resaltar la importancia de la ayuda recibida por los cooperadores. Las misas constituían la parte central de los momentos de piedad. Generalmente, una sola misa solemne, rezada por el obispo o alguna otra autoridad diocesana con la participación de las autoridades y de los cooperadores, ocupaba el programa matutino de los festejos. Para algunas ocasiones especiales, esta misa tomaba forma de tedeum en la catedral, pero previamente solían rezarse misas más sencillas destinadas a los niños y jóvenes del oratorio y el colegio y las llamadas misas de "comunión general" para los vecinos y la comunidad. Reforzando el carácter religioso de la educación impartida a los alumnos, eran de gran importancia las celebraciones conmemorativas de los meses dedicados a la virgen como la de algunos santos representativos. En este sentido, se destacaba la procesión anual en honor de la patrona de los salesianos, María Auxiliadora. En los primeros años, esta fiesta no pasaba de ser una sencilla celebración piadosa destinada sobre todo para los alumnos del colegio, los cooperadores y aquellos que simpatizaban con la obra. Pero con el paso del tiempo, la sofisticación de esa fiesta tan importante para la vida interna de la institución fue en aumento. Hacia 1913, ocho años después de llegados los salesianos a Córdoba, tenía lugar la primera procesión de María Auxiliadora por las calles de la ciudad. Durante los días previos a la fecha de la procesión se acostumbraba realizar una novena destinada al público en general, con algunas conferencias dictadas por cooperadores y sacerdotes, siendo también una ocasión propicia para la bendición de banderas y estandartes de la virgen que las diversas cofradías y asociacio- 
nes de laicos llevaban con orgullo en la procesión.

Estos actos rituales, con sus emblemas y símbolos - las cruces, banderas, estandartes, uniformes- constituían otra manera de generar la adhesión de los asistidos y del pueblo en general a un modelo de sociedad anclada en los valores cristianos, reforzando la cohesión social en momentos donde la cuestión social representaba una seria amenaza de fractura de la sociedad.

El modelo de interdependencia del Estado y las asociaciones en relación con la asistencia social y al proyecto civilizador, adquiría también formas rituales que reforzaban su legitimación. Ello se manifestaba tanto en la presencia de las autoridades en los actos de beneficencia (colectas, reparto de comida y ropa, funciones teatrales) como en las adhesiones que las instituciones benéficas realizaban a los homenajes públicos y fiestas patrias. En el primer caso, un acontecimiento tradicional era la entrega de los "premios a la virtud" en un acto en el Teatro Rivera Indarte por parte no sólo de la elite femenina de la Sociedad de Beneficencia, sino también por el gobierno y las instituciones políticas, con lo que se buscaba reforzar el modelo de asistencia social. En el segundo caso, las fiestas patrias eran una oportunidad privilegiada para demostrar la adhesión de las elites asistenciales al proyecto civilizador de la elite gobernante y para cultivar las relaciones de cercanía con los espacios de poder institucionalizados, que subsidiaban a las entidades para su funcionamiento, le garantizaban un lugar preponderante en el espacio asistencial y en el manejo de los pobres y en el mantenimiento del orden social. En las festividades patrias se ponía particular énfasis en destacar cómo los niños, asila- dos, huérfanos y pobres eran instruidos en los más puros sentimientos de nacionalidad y amor a la patria. La escenografía de estas celebraciones tendía a ensalzar la tríada patria, ejército y religión como garantía de orden y progreso de la sociedad. En efecto, superadas las tensiones entre ambas esferas del poder gestadas en la década de 1880, durante los primeros años del siglo $\mathrm{XX}$ y sobre todo hacia el centenario, se reconocía por parte de las elites gobernantes que la Iglesia era un baluarte insustituible del orden social y el catolicismo un elemento irrenunciable de la nacionalidad. La religiosidad constituía una dimensión que permitía amalgamar la población heterogénea y cimentar, mediante formas rituales y devociones específicas, su nacionalización. Esa amalgama era una expresión de la ambigüedad que mantenía el liberalismo argentino de esa época con los sectores católicos (Blasco, 2002, pp. 49-76). Así, en ocasión de los festejos del centenario de la Revolución de Mayo, tuvo lugar en el colegio Pío X una "hermosa academia literario musical a la patria”, donde se declamaron composiciones y diálogos con títulos como "San Martín y Aníbal”, "Los granaderos de San Martín” y "Saludo a la bandera" (Massa, 1930, p. 76).

Los actos gimnásticos de los colegios salesianos eran un componente relevante en ocasión de las festividades cívicas y exhibían la ejecución de juegos y maniobras simétricamente realizados por decenas de niños y jóvenes uniformados. Estas destrezas y ejercicios físicos se enmarcaron en un contexto donde la educación física era atravesada por diferentes discursos que entendían de diferente manera el desarrollo de esta disciplina en la escuela. El creciente militarismo producto del conflicto 
limítrofe con Chile hacia fines del siglo XIX y principios del $\mathrm{XX}$, sumado a un clima internacional que acentuaba la fuerte competencia entre naciones, llevó a que grupos pertenecientes al ejército, clubes y asociaciones deportivas fomentaran un enfoque militarista que entendía a la educación física como una instrucción militar y veía a la institución educativa como una escuela del soldado (Bertoni, 1996, p. 35). Por otro lado, el entusiasmo expresado en las celebraciones patrióticas se trasladaba, además, a las exhibiciones deportivas y gimnásticas a las que se les atribuía un "valor moral, según una concepción que entendía la actividad física como manifestación de la unión ideal del cuerpo y el alma, en su más plena entrega a la patria" (Bertoni, 1996, p. 41).

La influencia del estilo de educación física militarista quedó evidenciado también en el uniforme que vestían los alumnos en los desfiles y ejercicios físicos. Buscando la uniformidad y la prolijidad y haciendo una clara referencia a los colores de la bandera nacional, el "traje sport" de los alumnos del Pio X se componía de boina azul oscura, corbata celeste, camisa sport blanca y cinto trenzado celeste y blanco, completado por un pantalón azul marino, medias negras y zapatillas blancas. ${ }^{16}$ De esta manera, se presentaba el paso de los gimnastas escolares con un tono nacionalista:

Ostentando, el cuerpo de Gimnastas, en el color de sus uniformes los colores de la azul y blanca bandera de su patria que juran

${ }^{16}$ Folleto dirigido a los señores padres de familia de la sección externos. Colegio Pío X. Década de 1930. Archivo Colegio Pio X (ACPX), Córdoba, Argentina. defender, se presentan al mundo, ebrios de coraje y pletórico el corazón de juveniles entusiasmos, como la esperanza más grande de una patria querida a quien deben llevar por las vías del progreso y de la civilización. $^{17}$

En esta misma línea de acción, en la Memoria del Círculo de Obreros de San Vicente de 1926, se testimonia la concepción de la asistencia social como un acto de patriotismo, de crucial importancia para el proyecto de las elites gobernantes:

Como la finalidad de estos círculos de obreros que, como estandartes de avanzada de los trabajadores de orden y de progreso. [...] no solamente es de socorros mutuos, vale decir sólo material, sino que principalmente tiende a ilustrar y educar a las masas obreras en los grandes ideales de Dios y de la Patria; o lo que es lo mismo: a moralizarlas y enfervorizarlas; nuestro círculo ha estado atento y ha sido oportuno en adherirse, teniendo a tal fin, a todos los acontecimientos públicos celebrados en homenaje a instituciones o personalidades de nuestra patria y fuera de ella. Así por ejemplo con nuestro ejército nacional, cuando las maniobras del año pasado, en que Córdoba entera le tributó cariño y simpatía, nuestra institución fue la única obrera que en sentida y meditada nota saludó en la persona de su generalísimo, el general José Uriburu, a sus huestes gloriosas. [...] el 25 de mayo se conmemoró con carácter de fiesta oficial del Círculo, lo que se hará todos los aniversarios. A tal efecto se hizo oficiar en la iglesia parroquial de este pueblo un solemne

${ }^{17}$ Solemne distribución de premios. Colegio Pío X. Año1929, p. 27. ACPX, Córdoba, Argentina. 
Te-Deum con orador sagrado y cantores escogidos. ${ }^{18}$

\section{LUGARES DE ESPARCIMIENTO Y CONTROL: LAS REPRESENTACIONES TEATRALES, EL CINE, Y LOS ESPACIOS DE LECTURA}

Los espacios de esparcimiento adquirieron un lugar central para la cooptación de los asistidos y para el ejercicio de los mecanismos de control, a través de una "atenta vigilancia” sobre los contenidos transmitidos e inculcados en los usos del tiempo libre. Y en este aspecto, la acción de las elites asistenciales no se limitó a conjurar los peligros de la penetración de las ideas anarquistas, socialistas y fuertemente laicistas o a obturar representaciones reñidas con la moral religiosa, sino que ellas no escatimaron las tensiones y los conflictos que acompañaron sus intentos de hegemonizar el campo sociocultural, auspiciando iniciativas y poniendo en práctica diferentes representaciones culturales como parte de su pedagogía social de filiación católica.

Las comedias infantiles que se exhibían a las niñas de los colegios y de los asilos constituían, por su contenido doctrinario, una estrategia muy asiduamente utilizada para generar consenso con el modelo educativo y de sociedad. Era el caso de la comedia ejemplificadora dedicada a historiar la trayectoria biográfica de Santa Rosa de Viterbo, que se exhibió para las niñas de los colegios de las hermanas terciarias como

modelo y guía de las niñas, con el fin que se educasen en la fe, la pureza y la virtud:

${ }^{18}$ Serie Documentos. Año 1926. T. A-2-86, f. 414. 32. AHMC, Argentina.
La conducta de Rosa es el espejo en que debéis miraros... exhortándolas a imitar la inocencia y la modestia, la devoción y la humildad, la sencillez y la obediencia de la ilustre niña de Viterbo así como sus prácticas virtuosas y sus valores. ${ }^{19}$

Las funciones "lírico dramático-musical”, cantos, cuadros poéticos, diálogos y obras de teatro de contenido moral eran otras de las actividades en las cuales los alumnos de los colegios salesianos tenían oportunidad de expresarse. Las comedias, dramas, farsas, zarzuelas y sainetes puestas en escenas en la vida de las distintas instituciones y abiertas al público, en su gran mayoría, constituían verdaderos manuales del buen hijo, alumno, obrero o pobre. Los personajes y sus acciones representaban los valores éticos y morales, las formas de conducta y las maneras de obrar esperables en un niño o adulto cristiano, a la vez que mostraban las diferencias entre las buenas acciones y las consecuencias aparejadas de una vida en la mentira, la holgazanería, la mala conducta y el escaso celo religioso. A modo de ejemplo, es ilustrativa la comedia titulada Veinte años después, escrita por un sacerdote salesiano, que narraba el reencuentro, luego de dos décadas, de un grupo de niños compañeros de colegio. De una manera explícita, se mostraba el devenir de cada uno de ellos vinculando directamente las acciones de su pasado como escolares y el presente de su vida adulta. Así, de los cinco amiguitos, aquellos tres que mostraban constancia, esmero y esfuerzo en el

19 Santa Rosa de Viterbo. Comedia Infantil en un acto y en verso, dedicado a las alumnas de las hermanas Terciarias de San Francisco de Asís. Barcelona 1878. 
estudio y cumplimiento de sus obligaciones, de grandes llegaron a ser capitán de navío, sacerdote y comerciante, respectivamente. En cambio, aquel que en su infancia se mostraba perezoso, irresponsable y poco afecto al estudio, tuvo que conformarse con el "vil oficio de changador". Sin ahorrar componentes trágicos, la trama muestra al quinto protagonista, quien en su infancia osaba escaparse de clase, hablando mal de los maestros, de los compañeros que se apegaban a las normas y desafiaba la autoridad establecida, terminando su vida como mendigo, lamentándose por ser un "infeliz, un miserable, el más desgraciado de los hombres”, suplicando por comida en las calles. La moraleja, lejos de dejarla librada a la interpretación de los espectadores, se hacía explicita hacia el final de la obra en palabras de uno de los personajes:

¡Queridos niños! Ahora ponemos término a esta sencilla comedia, compuesta con el único objeto de educaros, de formar nuestro corazón. ¿Qué seréis vosotros de aquí a veinte años? Yo no sé $[. .$.$] lo que sé de cierto$ es que vosotros seréis lo que sois ahora en el colegio. Habéis visto las esplendidas carreras que consiguieron esos que fueron hijos obedientes, discípulos sumisos y respetuosos, y el fin desgraciado de aquellos que no escucharon los consejos y correcciones de sus padres y maestros. Sed siempre hijos obedientes y discípulos dóciles y algún día os hallaréis contentos $[\ldots]^{20}$

Los salesianos también bregaron por el control del tiempo de ocio fundando el

${ }^{20}$ Comedia en dos actos. Veinte años después. Imp. Colegio Pío IX, 1905. ACPX, Córdoba, Argentina. batallón de Exploradores de Don Bosco del que participaban los jóvenes que frecuentaban con "más regularidad y buena conducta” el Oratorio Festivo "que entretenía en ocupación buena y provechosa, a tanta juventud alejándola del ocio y los prepara para ser más tarde buenos servidores de la patria: sanos, robustos, morales y elementos de disciplina y orden". ${ }^{21}$

La vigilancia sobre los espacios de recreación llevó a la Tercera Orden Franciscana a instalar, en 1919, el Biógrafo Córdoba, en la calle Entre Ríos, solicitando al gobierno la exención de impuestos de entradas y avisos teatrales. Pero lo interesante de destacar son los fundamentos que ponen de manifiesto explícitamente cómo el modelo benéfico-asistencial de filiación cristiana, con fuerte impronta moralizante, buscaba monopolizar y disciplinar el esparcimiento, la instrucción y la educación moral de los niños:

El Biógrafo Córdoba, señor, no es una empresa comercial. Es una fundación generosa en pro de la moralidad y la educación del pueblo que se propone utilizar el admirable invento del Cinematógrafo [...] dándole su aplicación natural y lícita y ofreciendo por su medio al público y especialmente a la juventud de nuestra capital la ocasión de esparcimiento sano y provechoso que no sólo procure al espíritu el necesario y conveniente solaz sino que á la vez instruya y eduque estimulando nobles sentimientos e ideales levantados. $^{22}$

${ }^{21}$ Folleto dirigido a los señores padres de familia de la sección externos. Colegio Pío X. Década de 1930. ACPX, Córdoba, Argentina.

${ }^{22}$ Serie Documentos. Año 1919. T. A-2-60, fs. 107-109. AHMC, Argentina. 
La difusión de la denominada "buena lectura" fue otra estrategia tendente a lograr un consenso activo interinstitucional como etapa previa a su difusión en amplios espacios y sectores de la sociedad, entendiendo por "buena lectura" las obras literarias, de erudición, obras instructivas, recreativas y la prensa católica, "todo aquello que pueda llenar con beneficio de la cultura y sin perjuicio de la moral, la necesidad de leer y proporcionar al espíritu una nutrición sana”. ${ }^{23}$ Pero esta iniciativa cultural no se circunscribió al ámbito de cada asociación, sino que se pensó como un mecanismo irradiador de cultura, propaganda y reproductora de consenso hacia los sectores más marginales a través de la organización de campañas de lectura, auspiciadas en 1922 por el Congreso Terciario Franciscano, enviando libros a los barrios apartados de la ciudad por medio de un vendedor ambulante $y$, al interior provincial, a través de los párrocos y de las estaciones de ferrocarriles. Estas campañas tendían a contrarrestar la influencia emprendida por los protestantes y los "mercachifles turcos". Acciones como estas eran representativas de un mix de estrategias educativas y de control hacia los sectores subalternos. ${ }^{24}$

Otra iniciativa fue la creación de bibliotecas, como la Biblioteca Benedito XV de la Tercera Orden Franciscana en Río Cuarto, en el año 1916, con la finalidad -expresada en su reglamento- de trabajar "en la propaganda de los buenos

${ }^{23}$ Tercer Congreso Terciario Franciscano de la Paz Cristina Argentino-Uruguayo. Buenos Aires, 1922, pp. 176-177.

${ }^{24}$ Tercer Congreso Terciario Franciscano de la Paz Cristina Argentino-Uruguayo, Buenos Aires, 1922, pp. 176-177. libros y defiendan a ellos y a todos los que de ellos dependan de las lecturas perniciosas a las virtudes cristianas y sociales". ${ }^{25}$

\section{PROTAGONISMO EDITORIAL E IDENTIDAD INSTITUCIONAL}

Las sociedades dedicadas a la protección social ejercieron un verdadero protagonismo editorial estrechamente vinculado con la tarea de propaganda, no sólo de los beneficios de su accionar social hacia los sectores subalternos, sino también como un canal para vehiculizar su pensamiento e influencia a favor de un tipo de organización social sustentada en el orden, el progreso y la moral de filiación cristiana en tiempos de profundas transformaciones políticas, sociales, económicas y culturales involucradas en la modernidad. En la primera década, esas prácticas adquirieron la modalidad de propaganda-poder dirigidas a la concientización de la acción social a través de la publicación de revistas o folletos propagandísticos que combinaron la profusión de imágenes con un texto autocomplaciente y en tono entusiasmado, cuando no exaltado. Su estilo edulcorado y entusiasta era sintomático de la imagen idílica que se quería transmitir de la vida de los protegidos, especialmente en el caso de los niños. En este aspecto, la Serie Vida fue una colección de folletos especialmente destinada a la propaganda de los ideales cristianos donde se publicaron trabajos del padre Palau, jesuita especialmente dedicado a

${ }^{25}$ Reglamento y Catálogo de la biblioteca Benedito XV de la venerable Orden Terciaria de San Francisco, Río Cuarto, año 1916. 
los jóvenes, y los folletos de la Serie Cultura, el primero de los cuales estaba dedicado a la escuela social católica, publicados por la Liga Argentina de la Juventud Católica.

Además, las memorias institucionales, los periódicos, los folletos, las ediciones conmemorativas y de congresos, las conferencias -entre otros- fueron una parte sustancial de ese protagonismo editorial que se propuso la difusión benefactora de las prácticas asistenciales, pero fundamentalmente generar una identidad puertas adentro como etapa previa y necesaria para replicar ese consenso y adhesión en el universo de todos los necesitados. Esas memorias, elaboradas por las distintas comisiones directivas de las diversas asociaciones tuvieron como objetivo principal dar cuenta de los trabajos realizados, recogiendo todos los datos útiles que resaltaran la importancia de la asistencia social brindada y de la obra educativa realizada. Las memorias anuales que presentaban las instituciones contenían el alcance y la magnitud de la acción social, moralizadora y civilizadora cometida, pero también contenían una finalidad propagandística con artículos alusivos en su mayoría de autores eclesiásticos y laicos de filiación católica, no sólo provinciales sino nacionales y extranjeros, donde se aunaba el énfasis en la necesidad de la protección social a los desheredados y la prosa laudatoria confesional que reivindicaba el modelo cristiano como el camino correcto para afrontar los desajustes sociales y llevar a cabo el proceso de civilización e inclusión tutelada. En otras palabras, eran portadoras de las representaciones de la elite asistencial y, en menor medida, de la de los necesitados, que daban sentido a la práctica benéfica.
Por otra parte, las obras realizadas fueron narradas con un tinte heroico, mientras que los logros alcanzados fueron escritos con una prosa que pretendía hacerlos admirables. Además, contenían una serie de imágenes, cuadros estadísticos y citas textuales a través de las cuales se buscaba construir un criterio de veracidad sobre lo que se afirmaba. La combinación de representaciones escritas y visuales configuró un potente dispositivo de comunicación a través del cual se desplegaba una imagen del pobre, del enfermo, del excluido, de las mujeres viudas, de los niños pobres y abandonados como necesitados y al asistente como redentor. Más aún, las memorias hacían gala de unas prácticas discursivas que transmitían los ideales que subyacían a ese modelo asistencial: "orden y compostura de los niños", con un conocimiento básico de lo que se consideraba cultura, trabajo en los adultos, "conformidad en los ancianos" y oclusión de las manifestaciones de "insubordinación" y todo ello sustentado por las leyes de la moral cristiana. ${ }^{26}$ Con respecto a este último aspecto, las representaciones contenidas como sujetos protectores, los convertía en los únicos indicados para amparar, civilizar y controlar a los nominados como "desheredados de la vida". Más aún, el discurso enfatizaba que sólo a través del tutelaje de la elite asistencial, que incluía tanto una instrucción católica y cívica como la inserción en el mundo del trabajo, los asistidos podían lograr la capacitación para la integración a una sociedad ordenada y sin conflictos

\footnotetext{
${ }^{26}$ Memoria de la Conferencia de señoras vicentinas “Santa Rosa de Viterbo", Río Cuarto, años 19321933, p. 9.
} 
Mande el poder sin tiranía, obedezca el súbdito sin servidumbre, legislen las Asambleas Representativas, para el bien de los habitantes del país, organismos vivos del cuerpo social, adminístrese la justicia con humanidad, distribúyase la fortuna y las cargas públicas con equidad, no sea la libertad licencia o desenfreno. Sea el derecho el respeto a lo ajeno y la seguridad del bien que es adquirido por el trabajo honrado; la familia un dulce y caliente hogar de indisolubles afectos. Reine la paz e impere sobre todo el amor y la virtud... El trabajo ennoblece y asegúranos el pan nuestro de cada día; la oración nos devuelve a Dios. ${ }^{27}$

Junto con las memorias, los discursos de los directores espirituales de las asociaciones de protección social tenían como objetivo la legitimación del modelo; es decir, constituía una práctica discursiva laudatoria que apelaba a la "magnanimidad" de las mujeres y a su voluntad como misioneras de la caridad, como sostenedoras del modelo benéfico asistencial:

todas tenemos obligaciones en nuestros hogares pero diariamente nos confortamos con una obra buena, aliviando el dolor del enfermo, formando hogares cristianos e infundiendo en los corazones infantiles la más sana educación. ${ }^{28}$

Pero al mismo tiempo, la retórica interpelaba también a "los ricos y favorecidos por la fortuna" para que hicieran uso de las prácticas caritativas, no escati-

27 Tercer Congreso Terciario Franciscano de la Paz Cristina Argentino-Uruguayo, Buenos Aires, 1922, p. 188.

${ }^{28}$ Memoria de Sociedad de Beneficencia de Río Cuarto, 1932-1934. mando recursos literarios como las odas y la poesía. En este sentido, en la memoria de la Asociación de Beneficencia de Río Cuarto, del año 1932, esa interpelación a favor de los pobres se hizo recordando las estrofas del renombrado Antonio de Trueba:

Verás al buérfano débil
Verás al caduco anciano
Verás a la triste viuda
Verás al artista inválido
Famélicos y ateridos
Cubiertos ; ay Dios; de harapos
Tu compasión implorando
Llora con ellos y cubre
Su desnudez con el manto
De la caridad, ; O rico
A la molicie entregado!
Mira que Dios premia al bueno,
Mira que castiga al malo
Mira que te mira Dios
Mira que te está mirando
Mira que te bas de morir
Sin saber cómo ni cuándo.

Estrofas estas que reivindicaban la manera paternalista de atender las dimensiones más críticas y deshumanizadas de la cuestión social.

Las conferencias de destacados católicos sociales eran siempre objeto de atención y de difusión por los órganos institucionales. En este sentido, en 1921, en la publicación del Tercer Congreso Terciario Franciscano de la Paz Cristina ArgentinoUruguayo se publicó la conferencia de un católico social militante, como Juan Cafferata, quien se explayaba acerca de su concepción sobre la cuestión social, considerando que era "en el fondo una cuestión moral que la ley es incapaz de resolver por sí sola porque en último término 
está librada a imperativos de conciencia [...] que sólo desaparecerá con la fraternidad cristina". ${ }^{29}$

Las publicaciones anuales que los colegios salesianos distribuían con motivo de la finalización del cierre del ciclo escolar, donde se consignaban el elenco de alumnos sobresalientes en las diferentes materias, era otra evidencia singular orientada a generar el consenso activo en la comunidad sobre los méritos de aquellos que mejor habían transitado el camino que los formaba como "buenos cristianos y honrados ciudadanos”. Bajo el título de Solemne distribución de premios, esa publicación destacaba los premios obtenidos por los alumnos artesanos y estudiantes en las diferentes disciplinas. Sin dudas, la mención más importante la constituía el premio en educación moral y religiosa; además, era proclamada la "corte de la doctrina cristiana", formada por los ganadores del certamen catequístico realizado anualmente. Toda esta simbología y teatralidad constituía una forma más mediante la cual fomentaban el sentido de pertenencia al colegio en niños y jóvenes que en su amplia mayoría carecían de un espacio de contención. La intención era destacar cómo aquellos jóvenes caracterizados por su "rudeza", rescatados de las inmoralidades y vicios de la calle, eran regenerados y convertidos en "modelos de cortesanía" y en exponentes de las virtudes y moral cristianas, del esfuerzo, el trabajo, la modestia y la piedad digna de los futuros "ciudadanos honrados" de la república.

La importancia dada a las prácticas editoriales se reflejaba de manera particular

29 Tercer Congreso Terciario Franciscano de la Paz Cristina Argentino-Uruguayo, Buenos Aires, 1922, pp. 140-153. en la tarea educativa de los salesianos. Desde sus orígenes, consideraron a la prensa como un excelente medio para sostener la religión católica. El mismo fundador de la congregación, Don Bosco, le concedió una gran importancia a lo que denominaba el "apostolado de la buena prensa”, por lo que favoreció el desarrollo de tipografías e imprentas para la edición de libros católicos que eran, en su gran mayoría, de su autoría, sino además impulsó el desarrollo de periódicos y publicaciones de tirada consecutiva. Entre ellos, el llamado Boletín Salesiano se convirtió en el principal medio de difusión de las obras benéficas de la congregación, sirviendo para "obtener limosnas, atrayendo el afecto de las personas". ${ }^{30}$ Creado en 1877, fue el órgano mensual del Cooperador Salesiano, donde se encontraban las normas oportunas para el cumplimiento del reglamento.

El taller de Imprenta y Encuadernación, inaugurado en 1926 como parte del plan de formación profesional y educación técnica de la Escuela de Artes y Oficios del colegio Pío X, a la vez que cumplía su tarea de formación de los futuros imprenteros y encuadernadores, se constituyó en un importante órgano de difusión de numerosas publicaciones religiosas. Hacia 1935 eran editados en los talleres del colegio más de 7000 ejemplares de periódicos y revistas católicas propias y de otras comunidades, entre las que se destacaban el periódico destinado a la comunidad italiana, Vita Coloniale; el avisador religioso de la parroquia María Auxiliadora, de entre seis o siete páginas de tirada semanal;

${ }^{30}$ Don Bosco en el mundo. Estudios monográficos sobre la Congregación Salesiana y el Instituto de las Hijas de María Auxiliadora, LDC, 1958, p. 159. 
las revistas parroquiales de devoción Unión y El Santuario, del Sagrado Corazón de María y los Padres Dominicos, respectivamente, y otras revistas internas del colegio dirigidas principalmente a los alumnos, como Mi Colegio y Mies Divina, destinadas a publicitar las actividades educativas y recreativas realizadas en los institutos salesianos y a despertar, mediante lecturas morales con mensajes de devoción y piedad, la vocación religiosa entre los jóvenes. ${ }^{31}$ Además de estas publicaciones periódicas, la imprenta funcionaba como proveedora de textos escolares y de formación moral y religiosa. Libros de lectura con la vida de santos, obras de teatro de contenido moral, historias de devociones marianas, publicaciones de actas de congresos de cooperadores, sumado a un sinnúmero de folletos, opúsculos y folletines informativos de todo tipo, eran producidos por los alumnos del colegio bajo la dirección de los maestros imprenteros, con maquinarias que "estaban a la vanguardia del progreso". 32

Otros periódicos, aunque de tirada no consecutiva, fueron los boletines del Círculo de Obreros de Córdoba y de Río Cuarto y, con motivo de la fiesta conmemorativa del VII Centenario de la fundación de la Orden Tercera Franciscana, se editó una hoja periódica denominada VII Centenario. En todos ellos se reseñaban las prácticas de acción social y se proporcionaba información sobre los eventos culturales.

${ }^{31}$ Monografía sobre la historia del taller de imprenta. ACPX, Argentina.

${ }^{32}$ Monografía sobre la historia del taller de imprenta. ACPX, Argentina.
LA MODERNIZACIÓN DEL PATERNALISMO, LA CUESTIÓN SOCIAL Y LAS PRÁCTICAS CULTURALES

Las carencias sociales se acrecentaron con motivo de la crisis económica de 1913 que produjo una sensible retracción de las actividades productivas y comerciales y por la desaceleración del crecimiento económico que se operó en la década de 1920 por la cuasi-estabilización de la producción agrícola-ganadera. En el contexto del avance del capitalismo, esa transformación implicó, por un lado, un aumento de la pobreza estructural; es decir, el incremento del número de mendigos y pobres permanentes y, por otro, la consolidación de un nuevo tipo de pobreza ligada al mundo del trabajo, definible por la precariedad de las condiciones de vida y de trabajo. Esa coyuntura produjo una intensificación del protagonismo de las asociaciones católicas de protección social. Una manifestación de ese proceso fue la ampliación del perfil de los sujetos asistidos que ya no se limitaba sólo a los desheredados de la vida sino también a la clase trabajadora, es decir a los obreros.

En ese contexto, en 1920, se constituyó el Centro Social Pro Trabajo bajo la dirección del padre José M. Liqueno y el doctor Garzón Agulla,

un grupo selecto de hombres de ponderación social, intelectual y económica empeñados en cooperar activamente en la tarea impuesta de conseguir para Córdoba un mayor bienestar entre la clase trabajadora [...] la equidad y la justicia en las relaciones sociales obreras, la consideración y el respeto mutuo entre las clases, las necesarias garantías de la libertad de trabajo, el orden en todas las soluciones de los conflictos que 
se planteen, la instrucción y la agremiación obrera. $^{33}$

Para ello se constituyeron varias comisiones, entre ellas las comisiones de proyectos y agremiación social obrera.

Por su parte, la Asociación Obrera de la Sagrada Familia reunió más de 500 adherentes, poseía oficina de correo postal, asistencia médica y bonificaciones en las casas de comercio para los obreros asociados.

El lento deslizamiento en el perfil de los asistidos se hizo evidente también en el cambio de la oferta asistencial de algunos asilos. Así, en 1927, la conferencia de San Ignacio de Loyola solicitó un subsidio extraordinario para la casa para obreras levantada en la calle Paraná 140, aduciendo que la finalidad del asilo que allí funcionaba había cambiado: antes era para familias pobres y abandonadas y ahora se proponía recibir en ella a las madres e hijas obreras. $^{34}$

Las acciones dirigidas a la organización de los obreros implicaron una modernización del paternalismo tradicional, con una fuerte base antiliberal y antisocialista, pero también con una preocupación por tomar distancia de las relaciones patriarcales más tradicionales, si bien todavía era perceptible un desnivel entre la enunciación discursiva y las prácticas sociales. Un ejemplo elocuente fue la realización de la asamblea de la Unión Popular y los Círculos de Obreros realizada en noviembre de 1920, donde se exterioriza esa cobertura hacia los sectores obreros y el deslizamiento discursivo:

\footnotetext{
${ }^{33}$ Los Principios, 15 de mayo de 1920, p. 1, c. 3 y 4 .

${ }^{34}$ Serie Documentos. Año 1927. T. A-2-85, f. 117. AHMC, Argentina.
}

no se hace nacionalismo con la mera veneración de las glorias viejas o de los símbolos patricios [...] sería un sarcasmo, una ironía y un embuste pretender que se hace obra nacionalista, por ejemplo, con sólo levantar con sus propios caudales un hospital o un asilo bautizándolo con el nombre de un patriota e inaugurarlo un 25 de mayo bajo los auspicios del Himno Nacional y de la vocación mágica de las efemérides si ese asilo se construye y se levanta con dinero acumulado, explotando con salarios de hambre y jornadas excesivas de trabajo a pobres mujeres que el industrialismo liberal en mala hora arrojó a las fábricas y que el egoísmo capitalista convirtió en derechos humanos [...] Querer dar unas migajas de limosna a las víctimas de la injusticia pasada es atentar contra el interés colectivo, contra el bien de la patria, contra la Justicia social. Que no se redime del grave pecado de la explotación solo con buscar asilo a una porción de víctimas hechas. Se hace nacionalismo procurando que los obreros tengan confianza en la sociedad que viven, cosa que ha de conseguirse cuando la ley proteja el trabajo, limitando a ocho horas la jornada dura y obligando que los pagos de jornales se hagan en dinero efectivo. ${ }^{35}$

En esa misma perspectiva, Los Principios, al insistir en el problema de la niñez abandonada y en la necesidad de inculcar el trabajo rural en los niños y jóvenes, afirmaba la necesidad de realizar

el paso de una orientación de la caridad argentina hacia el concepto social de la misma [...] la caridad transitoria individualmente realizada es de muy problemáti-

${ }^{35}$ Los Principios, 16 de diciembre de 1920, p. 2, c. 3-7.

Beatriz I. Moreyra y NicolÁs Domingo MorettI 
cos efectos porque ella no responde a una finalidad social, sino cuando más a la muy loable satisfacción de los sentimientos cristianos. ${ }^{36}$

Manifestaciones claras y precisas de la conformación de un protoestado social sobre la base de una modernización del paternalismo tradicional como etapa de transición hacia el reconocimiento de los derechos sociales por parte de las elites gobernantes. En este sentido, es importante resaltar que la asistencia vicentina mezclaba estrategias modernas y tradicionales. La retórica de sus reglamentos recuerda el viejo discurso católico de amar al pobre para salvar sus propias almas y ganarse las indulgencias que se otorgaban a las que participaban en las conferencias. Pero otras de sus obras no fueron meras continuaciones de viejas prácticas caritativas sino que las voluntarias no siempre aceptaban la pobreza como una condición normal sino que trataban de erradicar sus causas (Eraso, 2009, p. 74). Así lejos de exaltar al pobre, la filantropía vicentina procuraba cambiar las costumbres y valores populares. Las señoras no se limitaban a resolver las cuestiones religiosas sino que abarcaban la cuestión social del día.

En ausencia de una política social de la Iglesia, resalta el crédito político de la habilidad de las mujeres católicas para obtener fondos para sus programas de asistencia (Eraso, 2009, p. 224). En efecto, las matronas constituyeron pacientemente la reputación de buenas administradoras de los fondos ajenos, una cualidad que fue respetada igualmente por liberales y anticlericales.

\footnotetext{
${ }^{36}$ Los Principios, 15 de febrero de 1919, p. 1.
}

Este viraje en las prácticas asistenciales impactó en las culturales que comenzaron a experimentar un deslizamiento desde la modalidad propaganda-poder hacia una mayor preocupación por la situación y demandas sociales de los trabajadores con miras a un mejoramiento de las condiciones obreras y a concientizar sobre la importancia de la sanción de una legislación social que atendiera los fuertes desajustes sociales. Esa preocupación se hizo perceptible en la frecuente alusión a esas problemáticas sociales en el discurso periodístico de filiación católica y en los documentos, conferencias y publicaciones -folletos y revistas- emanados de las asociaciones de protección social.

Así, a partir de 1918 se proyectaron centros de estudios "los más populares posibles" que no se concebían como academias de estudio con un programa fijo, sino como espacios abiertos donde los trabajadores de las fábricas y talleres pudiesen asesorarse sobre sus problemas sociales $^{37} \mathrm{y}$, en 1919, se inauguraron conferencias populares para ilustrar a la clase trabajadora sobre sus derechos, a la vez que fueron tribunas abiertas para peticionar la sanción de una legislación obrera bajo los postulados del catolicismo social. Estas conferencias populares se realizaron en distintos barrios y paseos. En las del barrio General Paz y en el Paseo Sobremonte -organizadas por los Círculos Obreros, los Artesanos de San José y la Sociedad Católica Obrera Italiana- las temáticas abordadas giraban en torno a la armonía entre el capital y el trabajo, la necesidad de legislar sobre el trabajo femenino a domicilio - modalidad sujeta a

\footnotetext{
${ }^{37}$ Los Principios, 19 de diciembre de 1918, p. 1.
} 
graves distorsiones en sus condiciones y en los salarios percibidos- la justicia social, la Iglesia, la democracia y el socialismo, la propiedad y la libertad de trabajo, el salario mínimo y el abaratamiento de la vida. ${ }^{38}$

Así en el Boletín Mensual del Círculo de Obreros de Río Cuarto, que en la década de 1920 se denominó La lectura del obrero -sustitución del léxico que reflejaba los cambios en el contenido factual del lenguaje- se insistía en el objetivo de difundir las buenas doctrinas entre los obreros pero también sobre la necesidad de contribuir a la mayor instrucción y cultura de los mismos, a la función dignificadora del trabajo y a los beneficios de la ayuda mutua y el ahorro. ${ }^{39}$ En 1927 , profundizando la tendencia hacia la centralidad de la cuestión social y obrera en el modelo católico de asistencia social, los Círculos de Obreros pusieron en marcha la denominada "Semana social", iniciativa destinada, por un lado, a profundizar las enseñanzas sociales católicas y, por otro, al estudio de las reformas tendentes al bienestar común. La "Semana social" era considerada una expresión doctrinal, científica y práctica. ${ }^{40}$

Por su parte, la concepción social de la educación de los salesianos, anclada en la visión del trabajo como instrumento de regeneración moral y como herramienta de inclusión para aquellos "alumnos desheredados”, significó una modernización del paternalismo, diferenciándose de otras

${ }^{38}$ Los Principios, 4 de mayo de 1919, p. 1 y 10 de mayo de 1919, p. 1.

${ }^{39}$ Caja 87. Archivo Histórico del Convento de San Francisco (AHCSF), Argentina.

${ }^{40}$ Los Principios, 21 de octubre de 1927, p. 1 , c. 1 y 2 . congregaciones y obras religiosas que actuaban en la ciudad. La opción por los más pobres, eje del carisma de la Congregación, sumado al desarrollo de una educación práctica en los talleres de la Escuela de Artes y Oficios, operaba como una estrategia de inclusión de los alumnos en el circuito laboral.

En síntesis, si bien la administración de los sacramentos y la enseñanza de la religión siguieron siendo la puerta de entrada al mundo civilizado, estas instituciones consideraban que con esto no bastaba para integrar de manera definitiva a los marginales a la sociedad, de allí que, al lado de los discursos y las prácticas relacionadas con la evangelización, se ejecutaron otras relacionadas con los deberes patrióticos - la formación del ciudadano-, con la pedagogía social, con las actividades productivas y con el reconocimiento de ciertos derechos para paliar los desajustes humanos más críticos que generaba el avance del capitalismo.

\section{LAS PRÁCTICAS Y REPRESENTACIONES CULTURALES: ENTRE EL CONSENSO Y LA RESISTENCIA}

Las prácticas culturales tendentes a generar un consenso con la acción social de las asociaciones no constituyeron un proceso sin tensiones y conflictos; es decir, ellas no sólo reflejaron la cohesión social sino también las diferencias y resistencias que se manifestaron entre actores desigualmente dotados de poder. El desarrollo de las prácticas y dispositivos culturales que analizamos páginas arriba lograron seguramente construir un cierto consenso activo o al menos cierta conformidad dentro de los asistidos, producto de sus caren- 
cias de capital económico, social y cultural y, por ende, de su situación de dependencia y de la escasa oferta de servicios disponibles, lo que hizo menos complicada la tarea de vigilancia y control por parte de las instituciones. Más aún, los sectores pobres vieron en la ayuda de las asociaciones de protección social un mecanismo de supervivencia a través de distintas modalidades: la ayuda directa mediante la entrega de dinero o comestibles, el auxilio como complemento del magro jornal, la recomendación para obtener un albergue, para conseguir trabajo, para ser internada en algún hospital y/o para tramitar la jubilación a la vejez. Es decir, no eran sujetos inarticulados sometidos rígidamente al control social o disciplinamiento, sino más bien agentes históricos conscientes y activos que hacían uso y se beneficiaban del sistema asistencial o establecían relaciones de reciprocidad aunque desiguales con los detentadores de la asistencia. Por otra parte, en el aspecto laboral, hay que recordar que la enseñanza impartida en la mayoría de las asociaciones benéficas comprendía la adquisición de diferentes habilidades para la obtención de un jornal que permitiera atender las necesidades básicas. Además, los propios talleres para artesanos y costureras que poseían las asociaciones, las escuelas primarias y las nocturnas, le otorgaban a la relación un sentido de reciprocidad con miras a evitar la destitución futura de sus asistidos, a lo que se sumaba un recurso adicional proveniente de las ventas de los productos, para la continuidad y mantenimiento de la cadena asistencial. Al encontrarles puestos a los padres de familia y regalarles herramientas de trabajo, les permitían a estos valerse por sí mismos. Es el caso de las numerosas familias que solicitaban ayuda en las diferentes sedes de las Conferencias Vicentinas, porque evidentemente habían incorporado en sus estrategias de sobrevivencia, a través de la acción propagandística y del protagonismo editorial, los servicios de las mismas; utilizaban el sistema vicentino de vales para conseguir comidas y otros artículos. Otra estrategia bastante extendida era solicitar el aval de los dirigentes de instituciones para la obtención de un trabajo dependiente o actividad de comercio de baja calificación. En este aspecto, las vicentinas en sesión del año 1921 otorgaron al pobre Amaya la recomendación para que se pueda dedicar a la venta de cigarrillos; en ese mismo año, en sesión del 24 de abril, la conferencia decidió otorgar una ayuda extraordinaria a la pobre recomendada por el R. P. Taborda. El 9 de octubre del mismo año, el consocio Calixto Gómez daba cuenta de haber conseguido la jubilación para la vejez al pobre Ibarra y, el 30 de julio de 1922, ante la enfermedad de la pobre Gutiérrez con cinco hijos y una madre enferma, se le concedió una recomendación a su hijo César de catorce años para ingresar a la escuela de mecánica. ${ }^{41}$

Con la modernización del paternalismo, vastos sectores obreros participaron e incorporaron todas aquellas iniciativas tendentes a concientizarlos de sus derechos laborales. Es decir, los trabajadores, con una racionalidad limitada y contextual, usufructuaban la ayuda reglamentada por los marcos normativos y la proveniente de la interacción que mantenían con sus benefactores.

${ }^{41}$ Libro de Actas de la Conferencia Vicentina de La Merced. Año 1921, ff. 106 y 136 y 176. Archivo del Convento de la Merced de Córdoba (ACMC), Argentina. 
El alcance de ese consenso estuvo lejos de ser un proceso desprovisto de disonancias y de resistencias hacia las formas, modelos de vida y las prácticas impuestas desde arriba. En este sentido, los mismos documentos institucionales daban cuenta de las dificultades en la integración de algunos sectores, especialmente en el cumplimiento de las normas religiosas.

En su visita al Colegio Pío X en 1913, el padre inspector de los salesianos, José Vespignani, informaba a los maestros y superiores de la casa sobre las precauciones necesarias que había que tener frente a ciertos alumnos que al parecer no lograban despegarse de los "malos hábitos" aprendidos en la calle y constituían un peligro para los demás compañeros:

Entre los externos hay graves peligros, por cierto elemento callejero, que no ha entrado ni participa en la vida del colegio, y está esparcido en todas las clases, en pequeñas proporciones en los grados superiores, pero con sede principal en tercer grado y algo en las clases inferiores. Debe practicarse con este elemento peligroso la vigilancia que prescribe nuestro sistema preventivo y se recomienda la acción unida del prefecto y consejero para impedir las reuniones afuera del colegio y las reciprocas influencias de estos niños en las clases, donde hay maestros externos que no alcanzan prevenir y remediar estos males. ${ }^{42}$

Es fácil inferir la dificultad encontrada por los educadores en lograr la aceptación y el cumplimiento del reglamento y las normas institucionales por parte de niños y jóvenes que habían carecido de un espa-

${ }^{42}$ Memoriale. Visita Inspectorial Colegio Pío X. Año 1913. ACPX, Argentina. cio reglado y disciplinado como la familia y la escuela y cuya existencia había transcurrido lejos de ambientes cerrados y regulados como se les presentaba.

En la Memoria de la Unión Pía de San Antonio, se reconocía

la tarea de moralizar los hogares para iniciarlos en el camino de la virtud no era fácil, debemos muchas veces vernos obligados a rogarles, predicarles y atraerles y como a los niños por medio del obsequio ya sea en remedios, ropas, etc., para que se conviertan en forma en un hogar cristiano y cual sería nuestro pesar al ver que algunos de los cónyuges encontrándose moribundo no aceptaban los sacramentos por falta de fe; la misericordia de nuestro señor es tan grande, que gracias a ella, que aunque fuese a última hora los recibieron arrepentidos de verdad. ${ }^{43}$

Una manifestación clara que los asistidos eran actores conscientes en la construcción de la relación asistencial y no meros receptores pasivos, eran las distintas estrategias que debieron utilizar las visitadoras de pobres de las Conferencias de San Vicente de Paul para lograr adoctrinar a los subalternos:

Las visitadoras debían ser seleccionadas de acuerdo a la condición de los pobres, seleccionando para algunos casos una visitadora que se les imponga por la gravedad de sus maneras y su carácter, mientras que de otros no se obtendrá nada sin ganar su confianza a fuerza de paciencia, dulzura y perseverancia [...] las visitadoras deberán buscar todos los medios posibles para instruir a los pobres sobre sus deberes y para hacérselos compren-

${ }^{43}$ Memoria de la Pía Unión de San Antonio, pp. 6 y 7. 
der. Unas veces se entrará en materia por medio de una buena palabra dirigida al niño; otras veces por medio de un libro, de una imagen o de un crucifijo que se regale, o por una lectura edificante que se hace a un enfermo, se procura instruir, edificar y consolar [...]. Oremos para convertir a nuestros pobres. ${ }^{44}$

\section{CONSIDERACIONES FINALES}

Esta contribución constituye una aproximación a la significación de lo cultural en el análisis histórico como posibilidad historiográfica, en su contextualización y variabilidad temporales. A través de la misma, se ha intentado reconstruir la complejidad de la relación asistencial, mediante el estudio de las distintas y heterogéneas prácticas culturales articuladas por las diversas instituciones de protección social con miras a hegemonizar las respuestas a la cuestión social en las primeras tres décadas del siglo XX. Específicamente, se han reconstruido las estrategias culturales implementadas por las elites asistenciales tendentes a lograr un consenso activo que implicara la aceptación, no sólo del saber y la influencia del manejo asistencial de las organizaciones de asistencia social, sino su participación y compromiso en "la grandeza del país” por parte de los asistidos y de la sociedad en general. Esta perspectiva supone una posición equidistante tanto de la leyenda negra que otorgaba la centralidad explicativa a los mecanismos disciplinadores como de la visión laudatoria de algunos documentos oficiales que destacaban una

${ }^{44}$ Documentos. Año 1926. T. A-2-82, f. $107 \mathrm{v}$. AHMC, Argentina. imagen optimista, autocomplaciente y benévola de las instituciones asistenciales. En este sentido, las prácticas y representaciones culturales analizadas generaron entre los actores participantes un consenso relativo con ese modelo asistencial y relaciones de reciprocidad entre los actores sociales y estaban estrechamente relacionados con lo que significaba, para las primeras décadas del siglo XX, ser un "ciudadano, católico, laborioso y civilizado”. Por otra parte, el estudio de las prácticas culturales permite cuestionar la imagen estereotipada del modelo benéfico asistencial como distante de los discursos sobre el progreso y las transformaciones económicas, si se tiene en cuenta la labor que desarrollaron en los márgenes y en los marginales orientada a modificar las costumbres de las clases populares y a difundir el sentido del progreso entre las clases inferiores, estrategias no descontextualizadas, por cierto, de las relaciones de dependencia y de poder existentes en el campo asistencial. Lo que emerge a través del análisis de las prácticas, de las representaciones y de las autorrepresentaciones emanadas de los documentos institucionales es una forma particular de llevar a cabo el proceso de modernización en un periodo histórico en el cual, si bien la influencia del modelo societal católico era muy fuerte, se estaba operando una transformación no sólo económica, sino cultural, con la recepción de nuevas ideas acerca de la cuestión social y sus soluciones. Es decir, lo que se quiere señalar en este aspecto es que, frente a las perspectivas exclusivamente disciplinadoras, la acción de las asociaciones civiles de fuerte impronta religiosa operaron como correas de transmisión del proyecto de civilización emprendido por las elites locales en la medida 
que se propusieron la recuperación y ordenación de las clases desheredadas a través de la educación, la moralización de los comportamientos, la higienización y la dignidad del trabajo. Por otra parte, se trataba al mismo tiempo de vínculos de dominación y de dependencia. Como toda relación entre desiguales, estos vínculos comportaban una posición de autoridad, una subordinación a los principios emanados desde arriba, pero también la interacción y reciprocidad entre los sujetos participantes en la rutinización de las conductas de la vida cotidiana, en los ámbitos de trabajo y en los espacios de recreación.

Además, el análisis puntual al interior del espacio asistencial ha permitido comprobar que su evolución no fue lineal ni homogénea, sino que estuvo sujeta a inflexiones dotadas de significado para las prácticas y representaciones de los actores involucrados. En efecto, a partir de la primera posguerra, y por los factores contextuales analizados, se produjeron dos deslizamientos no menores. En primer lugar, la modernización del paternalismo que significó un distanciamiento al menos discursivo de prácticas tradicionales y un hito importante en la conformación de la asistencia como derecho porque implicaba, aun cuando estaba basada en la inferioridad o desamparo innato, algo muy distinto al discurso y a la práctica de la limosna. En segundo lugar, es importante resaltar que esa puesta en alocución por parte de los detentadores de las asociaciones de protección social se basaba en ciertas características de la política y de la sociedad provincial; entre estas, figuraban un creciente reconocimiento sobre la necesidad de los servicios sociales y una elite política que no logró extender las obliga- ciones del Estado al campo asistencial a tal punto de poner en peligro el modelo benéfico asistencial en el gran campo del bienestar social. ${ }^{45} \mathrm{~A}$ pesar de ello, pero no desconectado de ese mismo proceso, la modernización del paternalismo también implicó un posicionamiento defensivo para preservar la hegemonía del espacio asistencial frente a los avances del protoestado social a partir de la segunda década del siglo Xx. Eso explica que las asociaciones civiles siguieran teniendo un protagonismo central en el campo asistencial como una tendencia de larga duración. Prueba de ello es la creación -entre otrasa fines del periodo de la Asociación de Ayuda Mutua, que reunía "a distinguidas damas" de la sociedad cordobesa para proteger moral y materialmente a tanta persona que por distintas causas han quedado desamparadas. Una tendencia de largo plazo que retiene los mismos objetivos, mecanismos de reclutamiento del personal asistencial similares y las reiteradas interpelaciones a la moralización de las clases desheredadas. ${ }^{46}$ La vigencia de esta forma de acción social, con sus transformaciones coyunturales, permite, a su vez, repensar interpretaciones relativas a la decadencia del modelo benéfico asistencial. Si bien el avance del protoestado social fue un proceso importante en la conformación del futuro Estado social, ello no implicó la pérdida de protagonismo de las asociaciones civiles si se ponderan dos fenómenos no suficientemente considerados. Uno, que el mayor financiamiento estatal de las demandas sociales no alcanzó los niveles necesarios para la sustitución de otras for-

${ }^{45}$ La Voz del Interior, 25 de mayo de 1921, p. 21.

${ }^{46}$ Los Principios, 19 de abril de 1928 , p. 5, c. 2 y 3. 
mas de asistencia no estatales; en segundo lugar, porque las instituciones de protección social buscaron defender sus posiciones de poder en el campo asistencial.

El otro aspecto que interesa destacar, en consonancia con los trabajos más recientes de la historiografía latinoamericana y argentina sobre la asistencia social en la modernidad liberal (véase Eraso, 2009; Ortiz, 2009), es que las relaciones paternalistas tradicionales, basadas en la protección y la obediencia estaban arraigadas en la desigualdad de las partes integrantes, pero la parte dependiente no careció completamente de poder de negociación o resistencia, sobre todo si los asistidos sentían que el pacto paternalista no se cumplía.

En síntesis, la ayuda social no estaba destinada exclusivamente al control social ni era una actividad residual en el complejo proceso de construcción de un Estado social; por el contrario, se elaboraron soluciones a los conflictos sociales del periodo y se prefiguró una modernización de la asistencia. Más precisamente, las prácticas asistenciales constituyeron un mix de estrategias tradicionales y modernas, en el sentido que si bien la meta era asistir a los "desvalidos" y trabajadores, ellos constituyeron una nueva práctica organizada e institucionalizada. En definitiva, una narrativa históricamente construida que revela una pléyade de estrategias culturales tendentes a la búsqueda de consenso con el modelo de asistencia social prevaleciente y a la integración de los sectores marginales y excluidos a través del trabajo y la civilización de las costumbres, pero también reveladora de la dependencia, la negociación y la resistencia de los asistidos frente a las acciones implementadas por los detentadores de esa heterogénea red asistencial.

\section{LISTA DE REFERENCIAS}

-Bertoni, L. A. (1996). Soldados, gimnastas y escolares. La escuela y la formación de la nacionalidad a fines del siglo XIX. Boletín del Instituto de Historia Argentina y Americana Dr. Emilio Ravignani, tercera serie, 13, primer semestre.

-Blasco, M. E. (2002). La tradición colonial hispano-católica en Luján. El ciclo festivo del Centenario de la Revolución de Mayo. Anuario del IEHS, 17.

-Castel, R. (1997). La metamorfosis de la cuestión social. Una crónica del salariado, Buenos Aires: Paidós.

-Di Liscia, M. S. y Boholavsky, E. (eds.) (2005). Instituciones y formas de control social en América Latina. 1840-1940. Buenos Aires: UNGS.

-Don Bosco en el mundo (1958). Estudios monográficos sobre la Congregación Salesiana y el Instituto de las Hijas de María Auxiliadora. Turín: Elle di Ci.

-Eley, G. (2009). Una línea torcida. De la bistoria cultural a la bistoria de la sociedad. Universitat de Valencia.

-Eraso, Y. (2009). Maternalismo, religión y asistencia: La Sociedad de Señoras de San Vicente de Paul en Córdoba, Argentina. En Y. Eraso (comp.), Mujeres y asistencia social en Latinoamérica, siglos XIX y XX. Argentina, Colombia, México, Perú y Uruguay. Córdoba: Alción Editora.

-Evans, P. B., Rueschemeyer, D. y Skocpol, T. (eds.) (1985). Bringing the State Back In. Reino Unido: Cambridge University Press, 1985.

-Girbal, N. y Moreyra, B. (comp.) (2011). Producción de conocimiento y transferencia en las ciencias sociales. Buenos Aires: Imago Mundi.

-Hering Torres, M. y Pérez Benavides, A. C. (2012). Apuntes introductorios para una historia cultural desde Colombia. En M. Hering Torres y A. C. Pérez Benavides, Historia cultural desde Colombia. Categorías y debates. Bogotá: Universidad Nacional de Colombia/Pontificia Universidad Javeriana/Universidad de los Andes. 
-Lionetti, L. (2005). La función republicana de la escuela pública: la formación del ciudadano en Argentina a fines del siglo XIX. Revista Mexicana de Investigación Educativa, X (27).

-Massa, L. (1930). Memorias del colegio Pío X. Publicadas con motivo de las bodas de Plata de su fundación. 1905-1930. Córdoba: Imprenta Colegio Pío X.

-Moreyra, B. I. (2000). La política social: caridades, estado y sociedad civil en Córdoba (1900-1930). En B. Moreyra, F. Converso, M. B. González, F. J. Remedi, P. B. Roggio, Estado, mercado y sociedad. Córdoba, 1820-1950 (I). Córdoba: CEH-ANCPT.

-Moreyra, B. I. (2007). La historia social más allá del giro cultural. Algunas reflexiones (Cuadernos de Ideas 10). Santiago de Chile: Universidad Católica Silva Henríquez.

-Moreyra, B. I. (2009a). Cuestión social y politicas sociales en la Argentina. La modernidad periférica. Córdoba, 1900-1930. Buenos Aires: UNQ.

-Moreyra, B. I. (2009b). La modernidad periférica: vivir asilado en el modelo mixto de protección social. Córdoba, 1900-1930. En B. I. Moreyra y S. Mallo, Pensar y construir los grupos sociales: actores, prácticas y representaciones. Córdoba y Buenos Aires, siglos XVI-XX (pp. 363-404). Córdoba-La Plata: Centro de Estudios Históricos "Prof. Carlos S. A. Segreti".

-Ortiz Bergia, M. J. (2009). De caridades y derechos. La construcción de políticas sociales en el interior argentino. Córdoba 1930-1943. Córdoba: CEH.

-Remedi, F. (2001). Crecimiento, modernización y bienestar en Córdoba, 1915-1930. En B. Moreyra, F. Converso, M. B. González, F. J. Remedi, P. B. Roggio, Estado, mercado y sociedad. Córdoba, 1820-1950 (II). Córdoba: CEH-ANPCT.

-Suriano, J. (2000). La cuestión social en la Argentina. 1870-1943. Buenos Aires: Ed. La Colmena.

-Vagliente, P. J. (2010). Un liberalismo negociador con el clericalismo: revisando el aso- ciacionismo católico en Córdoba, 1891-1912. En G. Vidal y J. Blanco (comps.), Catolicismo y política en Córdoba, siglos XIX y XX. Córdoba: Ferreyra Editor.

-Vespignani, J. (1922). Circulares, cartas, avisos. Edición reservada para uso de los salesianos de la Inspectoría Argentina de San Francisco de Sales. Buenos Aires: Imprenta Colegio Pío IX.

-Vidal, G. (2002). El Círculo de Obreros de Córdoba (1897-1907). Algunas características del espacio público de una ciudad del interior. En G. Vidal y P. Vagliente (comps.), Por la señal de la cruz. Estudios sobre Iglesia católica y sociedad en Córdoba, s. XVII-XX. Córdoba: Ferreyra Editor.

-Vidal, G. (2012). Asociacionismo católico de Córdoba. Composición social de las comisiones directivas del círculo de obreras de Córdoba, 1897-1930. En G. Caretta e I. Zacca (comps.), Derroteros en la construcción de religiosidades. Sujetos, instituciones y poder en Sudamérica, siglos XVII al xx, Tucumán: UNSTA.

\section{OTRAS FUENTES}

\section{Archivos}

AHMC Archivo Histórico Municipalidad de Córdoba, Argentina.

ACPX Archivo Colegio Pío X, Argentina.

ACMC Archivo del Convento de La Merced de Córdoba, Argentina.

AHCSF Archivo Histórico del Convento de San Francisco, Argentina.

\section{Hemerografía}

Los Principios, 1907-1928, Córdoba. La Patria, 1905, 1907, Córdoba.

La Voz del Interior, 1905-1935, Córdoba. 